\title{
Interleukin-1-Induced Long-Lasting Changes in Hypothalamic Corticotropin-Releasing Hormone (CRH)-Neurons and Hyperresponsiveness of the Hypothalamus-Pituitary-Adrenal Axis
}

\author{
E. D. Schmidt, ${ }^{1}$ A. W. J. W. Janszen, ${ }^{1}$ F. G. Wouterlood, ${ }^{2}$ and F. J. H. Tilders ${ }^{1}$ \\ ${ }^{1}$ Graduate School Neurosciences Amsterdam, Research Institute Neurosciences Vrije Universiteit, Faculty of \\ Medicine, Department of Pharmacology, and 'Department of Anatomy, 1081 BT Amsterdam, The Netherlands
}

Hypothalamic CRH neurons that control ACTH secretion from the pituitary gland have secretory terminals in the external zone of the median eminence (ZEME). These neurons can coproduce vasopressin (AVP), a neuropeptide that potentiates the ACTH releasing effects of CRH. Recently, we found Increased AVP production in adult rats weeks after single exposure to a stressor, which may play a role in event-induced stress disorders. Here, we describe the long-term changes in the HPA axis of adult male rats following a single exposure to a stressor, the cytokine inter-

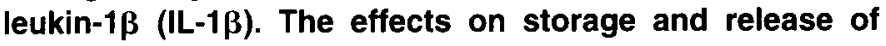
AVP and $\mathrm{CRH}$ were established by quantitative immunocytochemistry, the effects on ACTH and corticosterone responses by radioimmunoassay. Single administration of IL-1 $\beta$ (5 $\mu \mathrm{g} / \mathrm{kg}$ i.p.) induces a delayed (at least $4 \mathrm{~d}$ ) and a long-lasting (at least 3 weeks) increase of vasopressin (AVP) stores in CRH terminals of the ZEME without affecting the CRH stores, and a marked increase of the fraction of $\mathrm{CRH}$ terminals that costore AVP. Eleven days after IL-1 $\beta$ administration, a second IL-1 $\beta$ challenge causes a marked depletion of the AVP stores in the ZEME within $2 \mathrm{hr}$, which is not seen in rats treated with vehicle $11 \mathrm{~d}$ earlier. This is accompanied by twofold higher ACTH and corticosterone responses, as compared to those in vehicle pretreated rats. IL-1 $\beta$-pretreated rats also showed increased ACTH and corticosterone responses to electric footshocks. We conclude that transient activation of the HPA axis by a single administration of IL-1 $\beta$ induces a delayed and long-lasting hyperproduction, hyperstorage, and hypersecretion of AVP from hypothalamic CRH neurons that results in hyperresponsiveness of the HPA axis to subsequent stimuli.

[Key words: ACTH, corticosterone, corticotropin-releas-

\footnotetext{
Received May 4, 1995; revised July 11, 1995; accepted July 13, 1995.

We thank Dr. E. Kawashima (Glaxo, Geneva, Switzerland) for the gift of human recombinant IL-1 $\beta$, Drs. R. M. Buijs and F. W. van Leeuwen (Amsterdam, The Netherlands) for providing the anti-AVP antiserum "Truus," Dr. H. M. Gainer (Bethesda, MD) for providing monoclonal antibody PS4l against vasopressin-neurophysin, Dr. T. J. Benraad (Nijmegen, The Netherlands) for donating the corticosterone antiserum, and Dr. G. B. Makara (Budapest, Hungary) for providing the ACTH antibody. We thank Dr. J. H. A. Persoons for his help with the footshock experiments. Mr. R. Binnekade for his expert technical assistance, Dr. J. M. Ruijter for his advice with the statistics, and Mr. H. Nordsiek for reproducing the figures. This work was supported by a grant from the Dutch Foundation for Scientific Research (Nederlands Wetenschappelijk Onderzoek, NWO Grant 900-543-101).

Correspondence should be addressed to F. J. H. Tilders, Vrije Universiteit, Faculty of Medicinc, Department of Pharmacology, Van der Boechorststraat 7, 1081 BT Amsterdam, The Netherlands.

Copyright 1995 Society for Neuroscience 0270-6474/95/157417-10\$05.00/0)
}

ing hormone, hypothalamus-pituitary-adrenal axis, immunocytochemistry, interleukin-1, median eminence, rats, stress, vasopressin]

Hypothalamic CRH-producing neurons of the paraventricular nucleus (PVN), which control the secretion of ACTH from the pituitary, have secretory terminals in the external zone of the median eminence (ZEME). These neurons can coproduce AVP, a neuropeptide that strongly potentiates the ACTH releasing effect of CRH. Under resting conditions, 24-50\% of the $\mathrm{CRH}$ neurons are of the AVP coproducing phenotype (Whitnall et al., 1987b; Whitnall, 1988; Whitnall and Gainer, 1988; De Goeij et al., 1991; Bartanusz et al., 1993). During stress, the rate of secretion of CRH and AVP from the ZEME is determined by the nature and duration of the stressor, indicating that the two phenotypes (AVP coproducing and non-AVP producing) are differcntially controlled (Plotsky, 1985; Berkenbosch et al., 1989a,b; Tilders et al., 1989, 1993; De Goeij et al., 1991; Romero et al., 1993; Whitnall, 1993). Exposure of rats to chronic or repeated stress causes non-AVP-producing CRH neurons to shift towards the AVP coproducing phenotype (De Goeij et al., 1992c,d; Bartanusz et al., 1993; Tilders et al., 1993), resulting in a progressive increase of the AVP stores in the ZEME (De Goeij et al., 1991, 1992a,b; Bartanuse et al., 1993). In contrast to AVP, the $\mathrm{CRH}$ stores in the ZEME do not increase during chronic or repeated stress (De Goeij et al., 1991a,b). This phenotypic change is accompanied by increased release of AVP but not of CRH (Plotsky and Sawchenko, 1987; Aguilera et al., 1992; De Goeij et al., 1992a), and thus affects the hypothalamic signal driving ACTH secretion.

Recently, we reported that exposure of rats to a single session of unpredictable footshocks also increases AVP stores in the ZEME as measured 2 weeks later (van Dijken et al., 1993). At this time interval, increased ACTH responses as well as behavioral sensitization to an open-field stress are found (van Dijken et al., 1992a,b, 1993). This indicates that a single stressful event can induce long-term changes in $\mathrm{CRH}$ neurons that resemble those observed after chronic or repeated stress. Because of the potential impact of these findings we set out to analyze whether this long-term effect of was a stressor-specific phenomenon. Therefore, we studied the long-term responses to a stressor of a different nature, i.e., the cytokine II $-1 \beta$, that causes transient and CRH-dependent release of ACTH from the hypophysis (Berkenbosch et al., 1987, 1989a; Sapolsky et al., 1987; Uehara et al., 1987).

In the present article we describe the long-term effects of a 
single peripheral administration of IL-1 $\beta$ on the status and reactivity of the HPA axis. The effects on the AVP and CRH stores in the ZEME were established hy quantitative immunocytochemistry at the light- and electron-microscopic levels. To assess long-term effects on the responsiveness of the HPA axis, we measured ACTH and corticosterone responses to a challenge given 11 d later. Finally, we examined the long-term effects of IL- $1 \beta$ on the composition of the hypothalamic signal driving $\mathrm{ACTH}$ secretion during the second challenge with IL-1. We demonstrate that a single administration of IL- $1 \beta$ induces a delayed, but long-lasting increase of the AVP stores in CRH terminals in the ZEME, which is accompanied by an increased stress-induced release of AVP from the ZEME and an increased responsiveness of the HPA axis.

\section{Materials and Methods}

Animals. Male Wistar rats (I Iarlan, CPB, Zeist, The Netherlands), I60$180 \mathrm{gm}$ body weight, were housed two per cage under controlled light conditions (light period from 0700 to $1900 \mathrm{hr}$ ) at $22 \pm 2^{\circ} \mathrm{C}$, for $7 \mathrm{~d}$ prior to the beginning of the experiments. The experimental procedures were approved by the Animal Users Care Committee of the Vrije Universiteit. Food and water were available ad libitum.

$I L-I \beta$ treatment. Animals were subjected to noninvasive handling twice daily during $2-3$ d prior to i.p. administration of IL-1 $\beta$ or vehicle. IL-1 $\beta$ (recombinant hIL-1 $\beta$, Glaxo, Geneva, Switzerland) was diluted in endotoxin-free medium (vehicle) consisting of phosphate-buffered saline (PBS, $10 \mathrm{~mm} \mathrm{pH} \mathrm{7.3)} \mathrm{and} 0.01 \% \mathrm{w} / \mathrm{v}$ bovine serum albumin (BSA, Boseral, Organon-Teknika, Oss, The Netherlands). Aliquots were frozen and stored at $-70^{\circ} \mathrm{C}$. The biological activity of these preparations remained stable for at least 1 year. Appropriate dilutions of these preparations were made in vehicle just before the expcriments and kept on ice. Vehicle or IL-1 $\beta(5 \mu \mathrm{g} / \mathrm{kg})$ was injected i.p. $(1 \mathrm{ml})$ unless otherwise stated. Groups of 6-10 rats were sacrificed by decapitation at various time intervals thereafter.

In some experiments, rats that had been exposed to IL-1 $\beta$ or vehicle $11 \mathrm{~d}$ earlier, were given a second IL- $1 \beta$ challenge or were exposed to a single session of scrambled inescapable electric footshocks ( 80 shocks $0.4 \mathrm{~mA}, 5 \mathrm{sec}, 4$ per min, $20 \mathrm{~min}$ ). Animals were sacrificed by decapitation 90 or 120 min after the IL- $1 \beta$ challenge or immediately following the footshock session.

Radioimmunoassays. Trunk blood was collected in ice-cold heparincoated tubes and centrifuged $\left(1000 \times g, 15 \mathrm{~min}, 4^{\circ} \mathrm{C}\right)$. Aliquots of plasma were stored at $-20^{\circ} \mathrm{C}$ until assayed. ACTH concentrations were measured as described previously (Van Oers et al., 1992) using a specific antiserum (8514) directed against the midportion of ACTH (Kovacs and Makara, 1988). Synthetic rat ACTH (Peninsula, Belmont, CA) was used as a standard. The sensitivity of the assay was $10 \mathrm{pg} / \mathrm{ml}$ plasma $(0.5 \mathrm{pg} / \mathrm{tube})$. The intra- and interassay variations were $4 \%$ and $7 \%$, respectively. Plasma ACTH concentrations are expressed as $\mathrm{pg} / \mathrm{ml}$ plasma.

Plasma corticosterone levels were determined by RIA as described (Van Oers et al., 1992) using antiserum S-5230676 (de Man and Benraad, 1977). Corticosterone (Sigma, St. Louis, MO) was used as a standard. The sensitivity was $0.7 \mathrm{ng} / \mathrm{ml}$ plasma $(27.5 \mathrm{pg} /$ tube). The intraand interassay variations were $4.7 \%$ and $5.4 \%$, respectively. Plasma corticosterone concentrations are expressed as ng/ml plasma.

Immunofluorescence microscopy. Immediately following decapitation, the hypothalamus was dissected from the brain and fixed in $4 \%$ paraformaldehyde in $0.1 \mathrm{M}$ phosphatc buffer $\left(\mathrm{pH} \mathrm{7.6)}\right.$ ) for $2 \mathrm{hr}$ at $4^{\circ} \mathrm{C}$. Subsequently, tissues were incubated in $5 \%$ sucrose in $0.1 \mathrm{~m}$ phosphate buffer for $48 \mathrm{hr}$ at $4^{\circ} \mathrm{C}$. Hypothalami were trimmed, and up to $42 \mathrm{spec}-$ imen were embedded together in a cryomold containing OCT compound. Cryomolds were frozen in isopentane cooled with liquid nitrogen and serial frontal sections $(10 \mu \mathrm{m})$ were cut at $-20^{\circ} \mathrm{C}$ by using a motor-driven cryostat (Micron HM $500 \mathrm{M}$, Walldorf, Germany). Adjacent sections were incubated with rabbit anti-rat/human CRH antiserum (5Bo, 1:500) or with rabbit anti-AVP antiserum (Truus, 1:1000) for $2 \mathrm{~d}$ at $4^{\circ} \mathrm{C}$. The staining was completed by incubation with goat antirabbit antiserum conjugated to FITC (TAGO, Burlingham, CA) for 2 $\mathrm{hr}$ at room temperature $\left(21^{\circ} \mathrm{C}\right)$. Thereafter, the sections were mounted in Vectashield anti-fading medium (Vector, Burlingame, CA). For specificity of the CRH and AVP immunocytochemistry, see below. The antisera were diluted in "incubation buffer," which consists of $0.1 \mathrm{M}$ Tris-buffered saline (TBS, $\mathrm{pH} 7.6$ ) containing $0.5 \%$ Triton X-100, 0.2\% BSA, $1 \%$ normal goat serum (NGS, Dakopatts, Glostrup, Denmark), and $0.01 \%$ sodium azide.

Quantification of the immunocytochemical staining intensity was performed as described previously (Berkenbosch and Tilders, 1988; Tilders et al., 1989; De Goeij et al., 1991, 1992a,b,c, 1993) by using a computer-controlled microfluorimeter (Leitz-Combi, Leitz, Wetzlar, Germany). Previous validation studies in animals that were manipulated to achieve increases or decreases of the $\mathrm{CRH}$ content show that the data obtained by the quantitative immunocytochemical analysis are strongly correlated $(r=0.86-0.99)$ with data obtained by radioimmunassay (Berkenbosch et al., 1989b; Tilders et al., 1989). This demonstrates that changes as determined by the quantitative immunocytochemical analysis are proportional to changes in the amounts of CRH and AVP stored in the ZEME. Briefly, from each median eminence three sections were analyzed between the levels A 4100 and A 4500 according to Koenig and Klippel (57). In each section 10 measurements (spot dianeter 12.5 $\mu \mathrm{m})$ were made in the ZEME. In the same sections, six "background" measurements were collected in the arcuate nucleus, which does not show CRH or AVP immunostaining. After background subtraction, the mean fluorescence intensity was calculated for each ZEME.

Immunoelectron microscopy. Rats were anesthetized with sodium pentobarbital (12 mg/100 gm, Nembutal, Paris, France) and fixed by transaortic perfusion of the upper part of the body. Perfusion with 50 $\mathrm{ml}$ ice-cold tyrode buffer ( $\mathrm{pH}$ 7.6) was followed by $300 \mathrm{ml}$ of ice-cold fixative containing $4 \%$ paraformaldehyde and $0.25 \%$ glutaraldehyde in $0.1 \mathrm{M}$ phosphate buffer ( $\mathrm{pH} 7.6$ ). During fixation, the perfusion pressure was maintained at $10 \mathrm{mmI}$ Ig. After perfusion, the brains were removed and immersed in the fixative for $2 \mathrm{hr}$ at $4^{\circ} \mathrm{C}$. Subsequently, the median eminence was dissected, washed in $0.1 \mathrm{M}$ sodium-cacodylate buffer $(\mathrm{pH}$ 7.3) and postfixed with $1 \%$ osmium tetroxide in $0.1 \mathrm{M}$ sodium-cacodylate buffer for $1 \mathrm{hr}$ at $4^{\circ} \mathrm{C}$. After Araldite embedding, ultrathin $(80$ $\mathrm{nm}$ ) frontal sections were cut at three levels between $\mathrm{A} 4100$ and $\mathrm{A}$ 4500 according to Koenig and Klippel (57). The sections were collected on uncoated, 300 mesh high transmission nickel grids (Athene G2003N, Agar, Stansted, F.ngland) and processed for immunocytochemistry. For standardization of immunostaining, all sections from one experiment were processed simultaneously. The sections were subjected to either single or double immunostaining for CRH (rabbit antiserum 5Bo) or/ and vasopressin-neurophysin (AVP-NP, mouse monoclonal PS41) using gold-conjugated secondary antibodies. Primary antibodies and gold conjugates were diluted in incubation buffer consisting of PBS (pH 7.6) with $0.05 \%$ acetylated linearized BSA (BSA-C), $0.05 \%$ Tween $20 \mathrm{R}, 5 \%$ normal goat serum (NGS) (all reagents obtained from Aurion, Wageningen, The Netherlands) and $20 \mathrm{~mm}$ sodium azide. After etching with $3 \% \mathrm{H}_{2} \mathrm{O}_{2}\left(10 \mathrm{~min}, 21^{\circ} \mathrm{C}\right)$, washing and preincubation of the sections in incubation buffer (to block free aldehydes), they were incubated with 5Bo diluted 1:100 or PS41 diluted 1:100 or with a mixture of these antibodies (double staining). Immunostaining was completed with a mixture of goat anti-rabbit IgG conjugated with $15 \mathrm{~nm}$ gold particles (for demonstration of $\mathrm{CRH}$ ) and goat anti-mouse conjugated to $10 \mathrm{~nm}$ gold particles (for demonstration of AVP-NP; both conjugates were diluted 1:50 and werte obtained from Aurion (Wageningen. The Netherlands). Between incubations, sections were extensively washed. After the last incubation, sections were extensively washed and postfixed in $2.5 \%$ glutaraldehyde in phosphate-butfered saline $(\mathrm{pH} 7.6)$ for $20 \mathrm{~min}$ at $21^{\circ} \mathrm{C}$. After subsequent washing in water, the sections were contrasted with uranyl acetate $\left(5 \mathrm{~min} 40^{\circ} \mathrm{C}\right)$ and lead citrate $\left(4 \mathrm{~min} 20^{\circ} \mathrm{C}\right)$ in an LKB 2168 Ultrostainer and examined in an electron microscope (Phillips EM 300A).

CRH immunostaining was prevented by incubating antibody $5 \mathrm{Bo}$ with $10 \mu \mathrm{M} \mathrm{r} / \mathrm{hCRH} 41$ for $2 \mathrm{hr}$ at $37^{\circ} \mathrm{C}$. Incubation of sections with $5 \mathrm{~B}$ o or PS4I (single staining) followed by incubation with a mixture of gold-conjugated secondary antisera resulted in single/specific labeling with 10 or $15 \mathrm{~nm}$ gold particles, respectively, depending on the primary antibody. In a pilot experiment, the AVP and CRH labeling densities were examined by analyzing at least 200 secretory granule profiles per animal in randomly taken, standardized micrographs of the ZEME of two control animals (final magnification $\times 60,000$ ). Analysis of gold labeling of the individual secretory granules revealed that the labeling densities of CRH and AVP-NP were similar to those reported earlier (Bertini and Kiss, 1991): approximately 65\% of the secretory granules were labeled for CRH and about $30 \%$ for AVP. The labeling density for CRH was one to eight gold particles per secretory granule 
profile (approximately 200-1600 per $\mu \mathrm{m}^{2}$ ). The labeling densities for AVP ranged between one and six particles per profile $(200-1200$ per $\mu \mathrm{m}^{2}$ ). Background labeling with both antisera was less than 1.5 gold particles per $\mu \mathrm{m}^{2}$ tissue area and less than 0.5 particles per $\mu \mathrm{m}^{2}$ in the Araldite outside the tissue.

For the determination of the fraction of AVP-NP-labeled CRH terminals. $50 \mathrm{CRH}$ terminal profiles per animal were examined in two sections at different levels in the ZEME. A terminal profile was considered to represent a CRH terminal if it contained at least $10 \mathrm{CRH}$ labeled secretory vesicles. AVP-NP-containing CRH terminals contained at least two AVP-NP-labeled secretory vesicles.

Antibodies. For the specificity of the AVP antiserum "Truus" (provided by Dr. R. M. Buijs), see Van der Sluis et al., 1988).

The characteristics of the monoclonal antibody to AVP-neurophysin donated by Di. H. Gainer, are described elsewhere (Ben-Barak et al., 1985: Whitnall et al., 1985a).

The characteristics of antiserum $5 \mathrm{Bo}$, as seen in immunospot assays and in immunocytochemistry, are similar to those of the CRH antiserum 3B3 used in our previous studies (De Goeij et al., 1991, 1992a,b,c, 1993). Immunostaining was prevented by preincubation of $5 \mathrm{~B}$ o with 10 $\mu \mathrm{M} \mathrm{r} / \mathrm{hCRH} 41\left(2 \mathrm{hr}, 37^{\circ} \mathrm{C}\right)$, whereas no inhibition was seen after preincubation of $5 \mathrm{Bo}$ with up to $100 \mu \mathrm{M}$ AVP (Sigma. St. Louis, MO) oxytocin (Bachem Feinchemicalien) or $\alpha \mathrm{MSH}$ (Ciba Geigy. Basel, Switzerland).

Statistics. Data were analyzed by a one- or two-way analysis of variance followed by the Fisher Least Significant Difference test or by twotailed $t$ test, unless stated otherwise, using the NCSS statistical software program (Kaysville, UT).

\section{Results}

Single administration of IL- $1 \beta$ induces a marked, long-lasting increase in AVP stores of the ZEME. This becomes manifest with a delay of at least $4 \mathrm{~d}$, as illustrated in Figures 1 and 2 . Although AVP stores are not different 1 and $4 \mathrm{~d}$ after the IL$1 \beta$ challenge, they increased to $196 \%$ of vehicle-injected controls $7 \mathrm{~d}$ after IL- $1 \beta$ injection and remain high after $11 \mathrm{~d}$ (180 and $165 \%$ in experiment 1 and 2 , respectively). Twenty days after IL-1 $\beta$ injection, AVP is still elevated to $144 \%$ of that in vehicle-injected controls, but no differences between vehicle or IL-1 $\beta$-treated groups are found after $40 \mathrm{~d}$. Single administration of IL-1 $\beta$ does not induce changes in CRH content of the ZEME at any of the time intervals studied, with the exception of a small increase to $121 \%$ on day 20 . In a separate experiment, we found that the AVP and CRH stores of the ZEME of vehicle-injected animals do not differ from those of untreated controls at 4, 7 , 11 , or $20 \mathrm{~d}$ after injection (data not shown). Quantitative immunocytochemical measurements of the AVP stores in the internal zone of the median eminence, a zone that contains the projections of magnocellular AVP neurons to the neurohypophysis, reveals no differences between vehicle and IL-1 $\beta$-treated groups at any of the time intervals studied (data not shown).

To determine whether the IL-1 $\beta$-induced increases of the AVP stores in the ZEME are accompanied by changes in AVP content within the secretory terminals of the CRH neurons, median eminences obtained from rats injected with IL-1 $\beta$ or vehicle $11 \mathrm{~d}$ earlier were processed for immunoelectron microscopy. Analysis of the ultrathin immunogold double-labeled sections reveals the occurrence of AVP positive and of AVP negative $\mathrm{CRH}$ terminals in the ZEME of rats given vehicle or IL-1 $\beta 11$ d earlier (Fig. 3). Both CRH and AVP immunoreactivity is confined to dense-cored secretory granule profiles that have a mean diameter of approximately $90-100 \mathrm{~nm}$. Diameters do not differ between vehicle and IL- $1 \beta$ treated groups. Both types of $\mathrm{CRH}$ terminals contain clear vesicles with a diameter of approximately $40-50 \mathrm{~nm}$ both in vehicle and IL-1 $\beta$-treated groups (Fig. 3). In the AVP-containing population of $\mathrm{CRH}$ terminals, secretory granules are labeled to a variable degree for the two peptides.
Besides secretory granules showing both CRH and AVP immunoreactivity, other secretory granules are found that show only CRH or AVP immunoreactivity (Fig. 3). Quantitative analysis shows that the fraction of $\mathrm{CRH}$ terminals costoring AVP has increased from $40.3 \pm 4.1 \%$ in vehicle controls to $63.3 \pm$ $4.6 \%(p<0.01)$ in $\mathrm{IL}-1 \beta$-treated rats $11 \mathrm{~d}$ after single administration (Table 1). Further analysis reveals that there are no differences between vehicle and IL-l $\beta$-treated groups in the numbers of secretory granules per terminal profile (Table 2) nor in the labeling densitics of the sccretory granule profiles (Fig. 4). In both groups, approximately $40 \%$ of the secretory granule profiles are not labeled for CRH and $75 \%$ not labeled for AVP (Fig. 4). Furthermore, the CRH labeling densities of secretory granules in non-AVP-containing CRH terminals did not differ from that in AVP-containing CRH terminals (Fig. 4) for both vehicle and IL-1 $\beta$-treated groups. In the AVP-containing CRH terminals of both vehicle and IL-1 $\beta$-pretreated groups, about half of the AVP-labeled secretory granule profiles are singly labeled for AVP (59.6 and 55.3\%, respectively, data not shown). Terminals that are only labeled for AVP are only incidentally found in the ZEME and contained dense-cored secretory granules with a mean diameter of approximately $175 \mathrm{~nm}$, which is similar to those found in the zone interna of the median eminence and therefore are derived from magnocellular neurons.

The changes in the AVP stores in the ZEME as depicted in Figure 2 are not associated with reproducible changes in the resting levels of plasma $\mathrm{ACTH}$ or corticosterone as measured during the trough of the diurnal cycle. Analysis of these and of four additional experiments reveals that resting $\mathrm{ACTH}$ and corticosterone concentrations in plasma are significantly elevated in three out of six experiments at day 11 (increases were up to $125 \%$ and $400 \%$ of vehicle control levels for ACTH and corticosterone, respectively). Elevated ACTH and corticosterone levels are not correlated across the experiments. The mean plasma levels of vehicle treated controls in these experiments are 50 $74 \mathrm{pg} / \mathrm{ml} \mathrm{ACTH}$ and $3.5-35 \mathrm{ng} / \mathrm{ml}$ corticosterone, which is not different from values generally found in untreated controls in our animal facilities.

In order to determine possible long-term effects of single IL$1 \beta$ exposure on the responsiveness of the HPA axis to stressors, rats are given a second injection with either vehicle or IL- $1 \beta$ ( 1 $\mu \mathrm{g} / \mathrm{kg}) 11 \mathrm{~d}$ later, and plasma concentrations of $\mathrm{ACTH}$ and corticosterone are measured $2 \mathrm{hr}$ later, when these responses are (near) maximal (Berkenbosch et al., 1987; Uehara et al., 1987; Schotanus et al., 1993). In rats given vehicle $11 \mathrm{~d}$ earlier, administration of vehicle results in mean plasma ACTH and corticosterone levels of $56 \mathrm{pg} / \mathrm{ml}$ and $7 \mathrm{ng} / \mathrm{ml}$, respectively. Injection of vehicle in IL- $1 \beta$ pretreated rats results in slightly higher $(68 \pm 2 \mathrm{pg} / \mathrm{ml}, p<0.05)$ ACTH levels as compared to those of vehicle pretreated rats, but does not result in different $(10 \pm$ $3 \mathrm{ng} / \mathrm{ml}$ ) corticosterone levels. Administration of II.-I $\beta$ to vehicle-pretreated rats elevates plasma ACTH and corticosterone levels to $139 \pm 50 \mathrm{pg} / \mathrm{ml}$ and to $92 \pm 33 \mathrm{ng} / \mathrm{ml}$, respectively $(p$ $<0.01$ vs vehicle-injected controls). IL-1 $\beta$-induced ACTH and corticosterone levels in IL-1 $\beta$-pretreated rats are approximately twice as high as those found in vehicle-pretreated rats $(p<0.01)$ (Fig. 5) and are $284 \pm 36 \mathrm{pg} / \mathrm{ml}$ and $173 \pm 39 \mathrm{ng} / \mathrm{ml}$, respectively.

To study whether the IL-1 $\beta$-induced long-term hyperresponsiveness to IL- $1 \beta$ is stimulus specific, groups of rats that have been injected with vehicle or IL-1 $\beta 11 \mathrm{~d}$ earlier, are exposed to electric footshocks. Pilot studies revealed that after $20 \mathrm{~min}$ of 

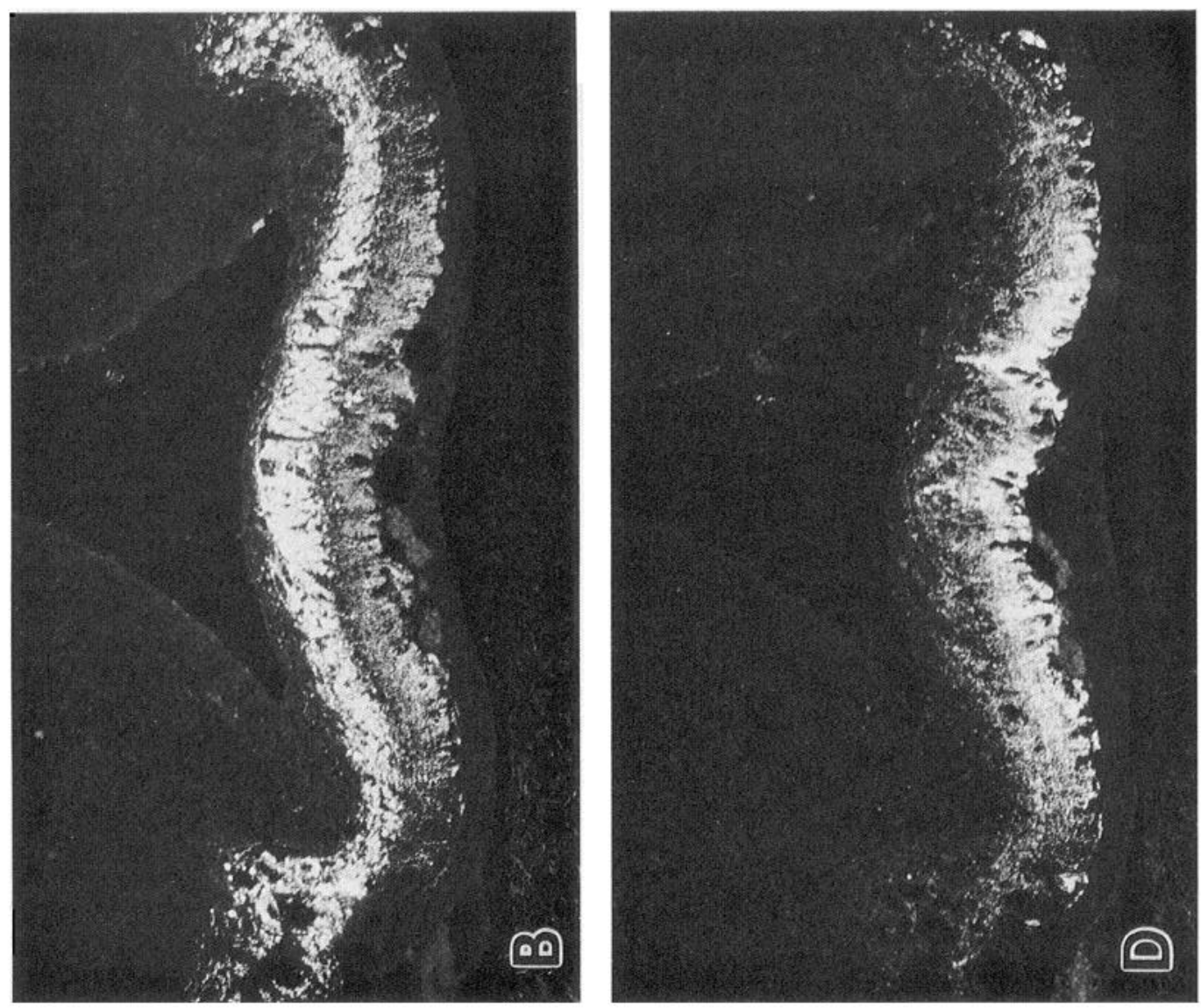

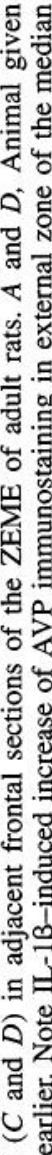
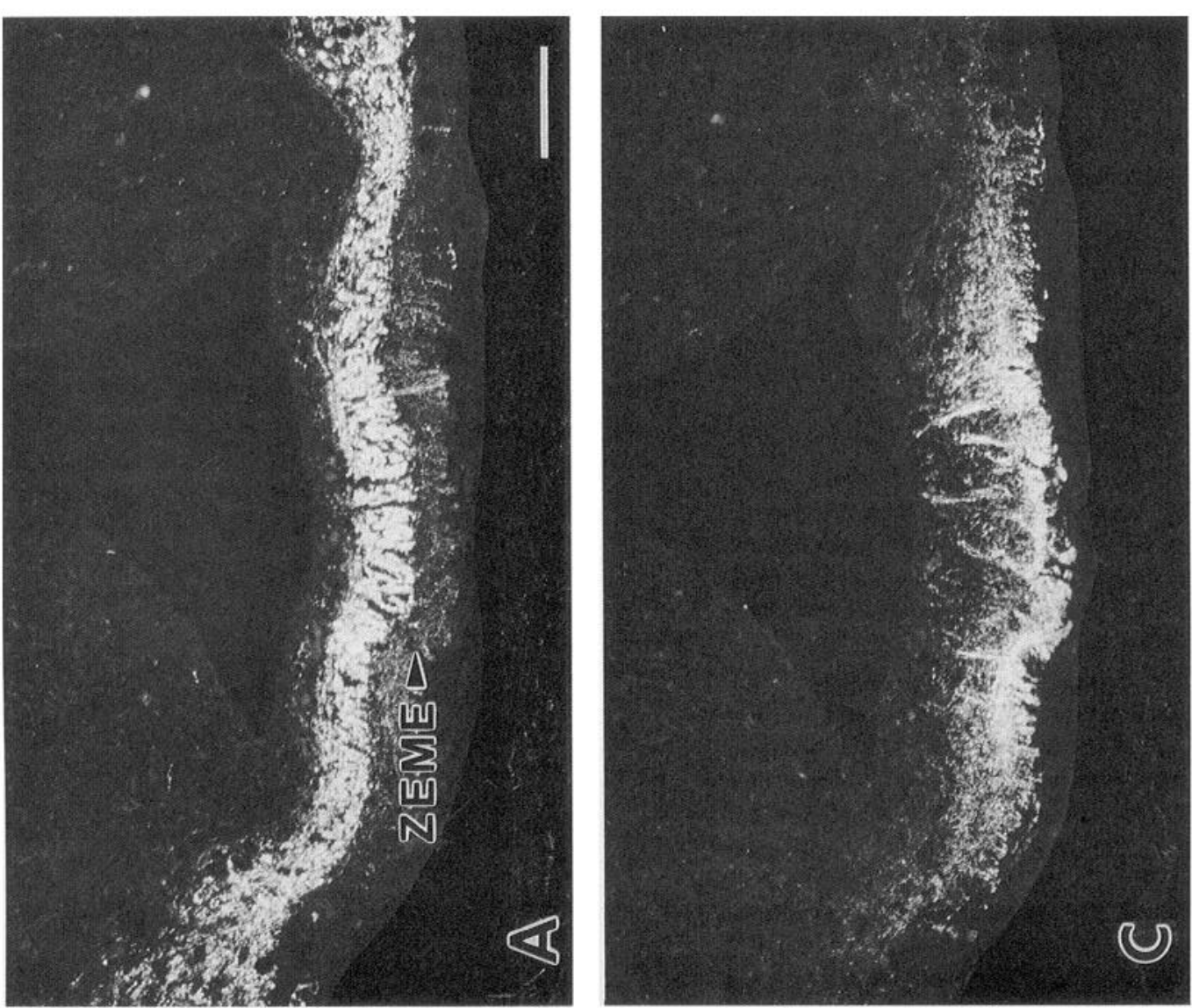

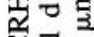

긍

도․

(1) ตำ

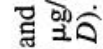

$\pi \cong$

은두

文手 哭

㟧茨.

on 대요

글

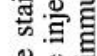

\& 2.

政

के

응.

롱용

볼 옹

․ㅡ.틈웅

에는

ลิ

ज्ञ

象电

茄㟧

을롫

远㤩

그요

는

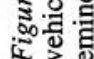



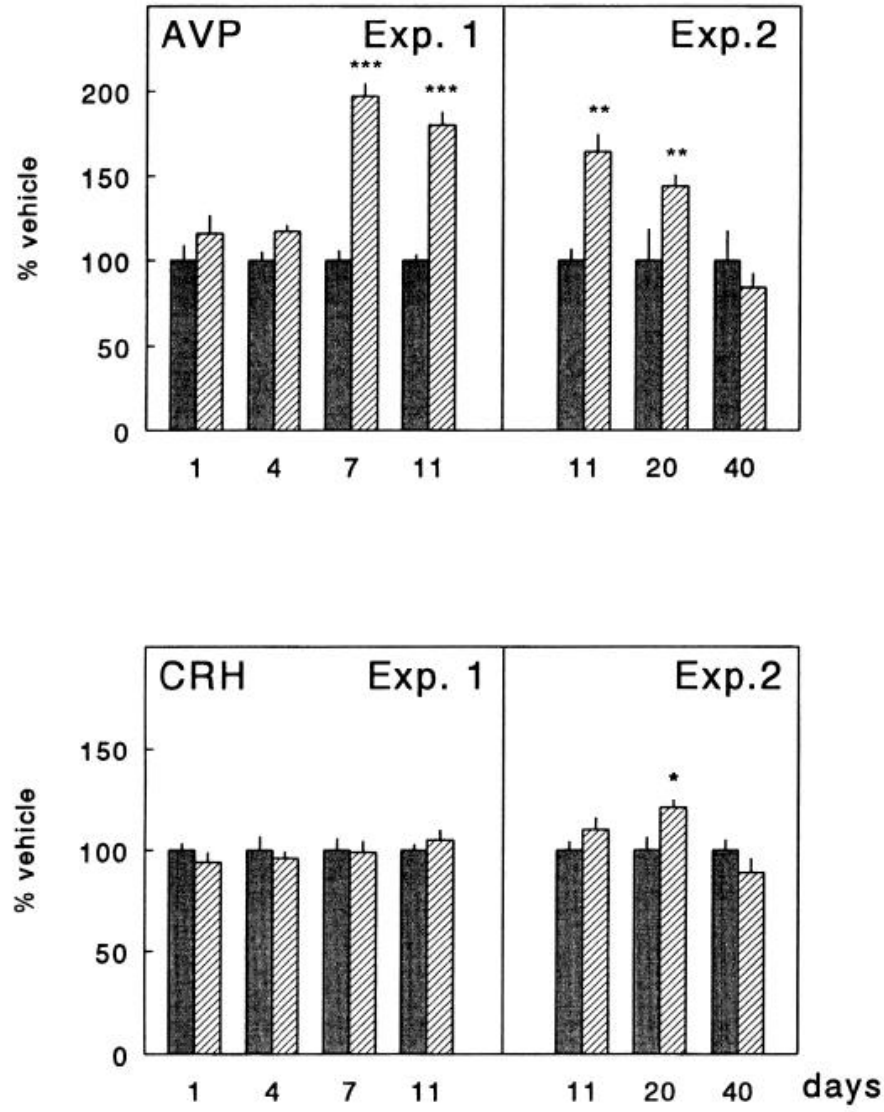

Figure 2. AVP and CRH in the ZEME at different intervals ( $1-40$ d) after a single administration of vehicle (gray bars) or IL-1 $\beta$ (hatched bars). Results from two independent experiments (experiment 1; experiment 2) are expressed as percentage of mean values of time-matched vehicle-treated groups. Data are presented as mean and SEM $(n=8)$. ${ }^{*} p<0.05,{ }^{* *} p<0.01,{ }^{* *} p<0.0001$ vs time-matched vehicle group.

footshocks, plasma ACTH levels are still high and corticosterone levels peak (data not shown). As illustrated in Figure 6, ACTH and corticosterone levels of footshocked rats are elevated in both vehicle and IL- $1 \beta$-pretreated groups ( $p<0.01$ vs untreated controls). However, the ACTH and corticosterone levels in the IL$1 \beta$-pretreated group are higher than those in the vehicle-pretreated group $(676 \pm 120 \mathrm{vs} 436 \pm 60 \mathrm{pg} / \mathrm{ml} \mathrm{ACTH}$ and 193 \pm 17 vs $150 \pm 8 \mathrm{ng} / \mathrm{ml}$ corticosterone, respectively $(p<0.05)$.

In view of our observations that exposure of rats to IL-1 $\beta$ induces hyperresponsiveness of ACTH to stimuli $11 \mathrm{~d}$ later, we studied the acute effects of a second IL-1 $\beta$ challenge on the peptide stores in the ZEME in IL- $1 \beta$ or vehicle pretreated groups. Data are obtained from the same experiment as shown in Figure 5. A pilot experiment revealed that vehicle challenge in vehicle or IL-1 $\beta$ pretreated rats does not affect the AVP or $\mathrm{CRH}$ stores as compared to those in unchallenged controls (data not shown). As illustrated in Figure 7, IL-1 $\beta$ does not lead to acute changes in the CRH or AVP stores in the ZEME of rats given vehicle $11 \mathrm{~d}$ earlier. In accordance with data presented in Figure 2, IL-1 $\beta$, given $11 \mathrm{~d}$ earlier, causes a significant increase $(p<0.001)$ of the AVP stores in the ZEME to $203 \%$ of vehiclepretreated controls, but no change in the CRH stores. In contrast to the absence of acute IL- $1 \beta$ effects in the vehicle-pretreated group, IL-1 $\beta$ causes a marked reduction of the elevated AVP

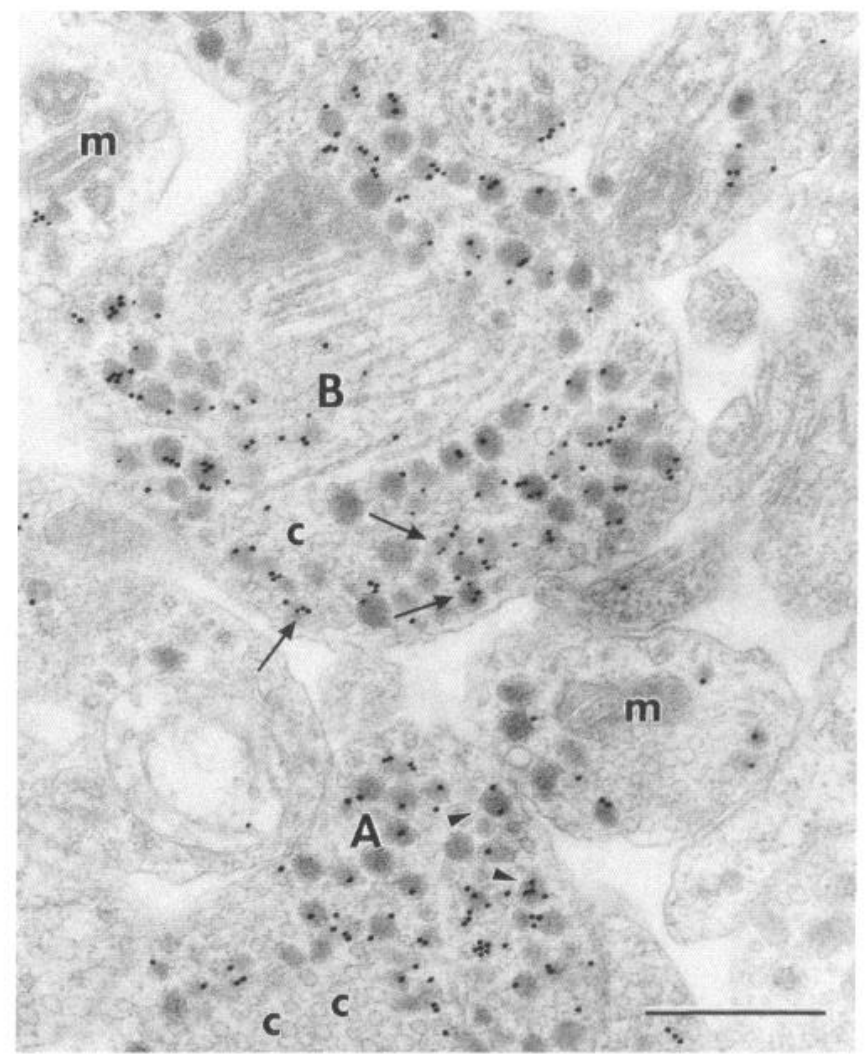

Figure 3. Electron micrograph showing two phenotypes of $\mathrm{CRH}$ terminals in the external zone of the median eminence of a rat. $A$, Terminal containing secretory granules showing only CRH immunoreactivity ( 15 $\mathrm{nm}$ gold, arrowheads). $B$, Terminal containing granules exhibiting immunoreactivity for CRH and/or AVP-neurophysin ( $10 \mathrm{~nm}$ gold particles, arrows). Note the heterogeneity in labeling density between granules. $c$ : clear vesicles; $m$ : mitochondrion. Bar: $500 \mathrm{~nm}$.

stores (44\% depletion, $p<0.01$ ), without a detectable decrease of the $\mathrm{CRH}$ content in the ZEME of IL-1 $\beta$-pretreated rats.

\section{Discussion}

In the present study we demonstrate that transient activation of hypothalamic $\mathrm{CRH}$ neurons of adult rats by a single peripheral administration of IL- $1 \beta$ induces a remarkable form of neuronal plasticity, i.e., a delayed and long-lasting increase of the AVP stores in CRH terminals of the ZEME. In addition, we provide evidence that this increase induces hypersecretion of AVP and a subsequent hypersecretion of ACTH and corticosterone in response to later stressors.

The increase of the AVP stores in the ZEME, which appears

Table 1. Long-term effect of IL-1ß on the phenotype of CRH terminals in the ZEME

\begin{tabular}{|c|c|c|c|}
\hline & \multicolumn{2}{|c|}{ Numbers of $\mathrm{CRH}$ terminal profiles } & \multirow{2}{*}{$\begin{array}{l}\text { AVP+ } \\
\% \text { total CRH }\end{array}$} \\
\hline & AVP+ & AVP- & \\
\hline VEH & $18.3 \pm 2.5$ & $27.7 \pm 3.4$ & $40.3 \pm 4.1$ \\
\hline IL-1 $\beta$ & $30.0 \pm 2.8$ & $17.5 \pm 2.4$ & $63.3 \pm 4.6^{*}$ \\
\hline
\end{tabular}

Eleven days after single administration of vehicle (VEH) or IL-1 $\beta$ rats were sacrificed. ZEME was analyzed by quantitative immunoelectron microscopy using postembedding immunogold double-labeling for CRH and AVP-NP. Data are presented as mean $\pm \operatorname{SEM}(n=4-5)$.

$* p<0.01$ versus $\mathrm{VEH}$. 
Table 2. Long-term effect of IL-1 $\beta$ on the numbers of secretory granules in CRH terminals

Number of secretory granules per CRH terminal profile

\begin{tabular}{lll} 
& \multicolumn{2}{l}{$\begin{array}{l}\text { Number of secretory granules } \\
\text { per CRH terminal profile }\end{array}$} \\
\cline { 2 - 3 } & AVP+ profiles & AVP- profiles \\
\hline VEH & $40.7 \pm 6.3$ & $38.7 \pm 4.2$ \\
IL-1 $\beta$ & $39.8 \pm 4.9$ & $44.6 \pm 5.5$
\end{tabular}

For details, see Table 1 note.
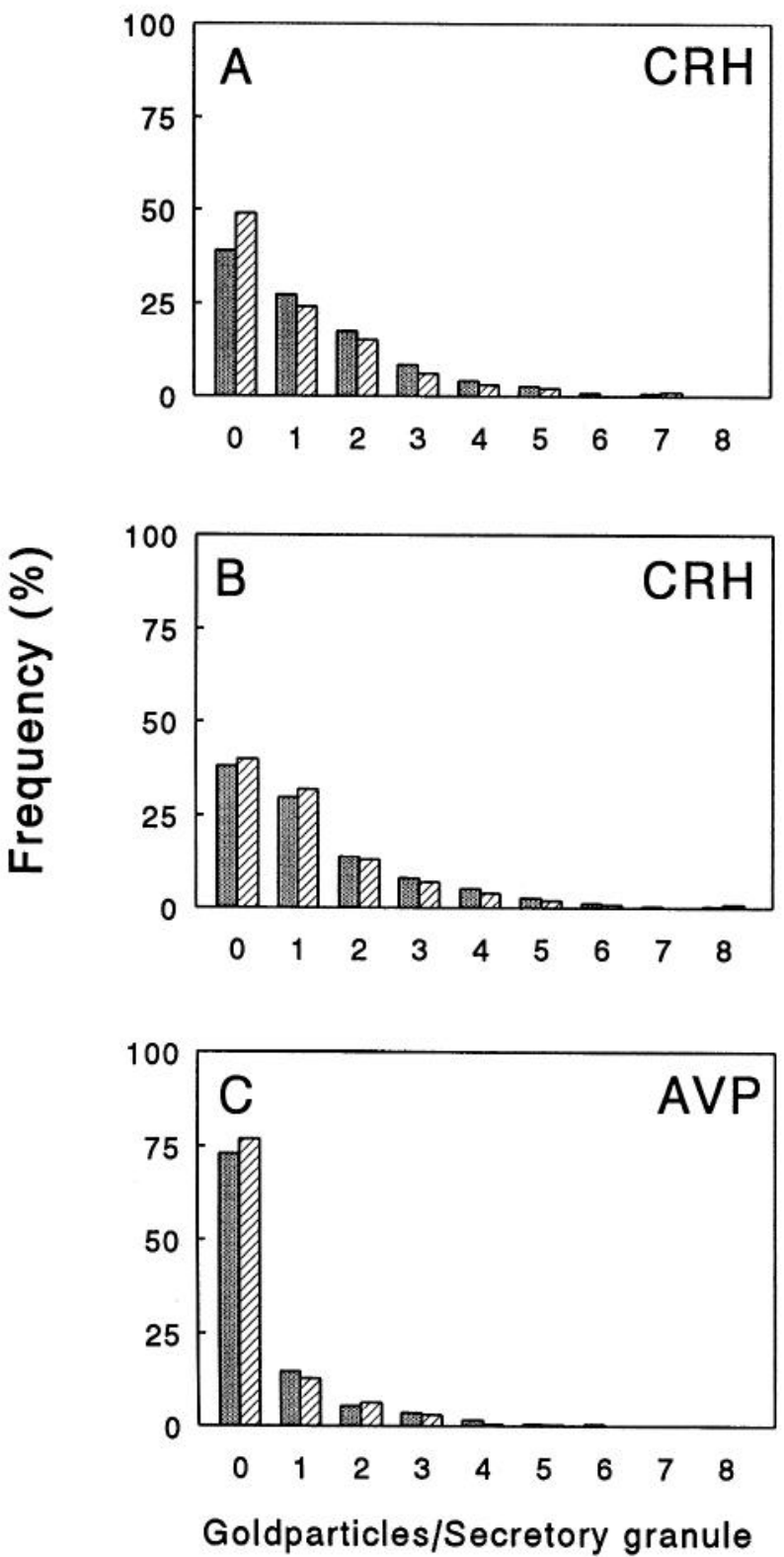

Figure 4. Frequency histograms of $\mathrm{CRH}$ and AVP-neurophysin labeling of secretory granules in CRH terminals of the ZEME. A, CRH labeling densities of secretory granules in non-AVP-containing CRH terminals. $B$, CRH labeling densities of secretory granules in AVP-containing CRH terminals. $C$, AVP labeling densities of secretory granules in AVP containing CRH terminals. (Each panel based on analysis of 600 secretory granules per rat, two per group). Bars show relative frequency versus the numbers of gold particles per secretory granule profile after a single administration of vehicle (gray bars) or of IL-1 $\beta$ (5 $\mu \mathrm{g} / \mathrm{kg}$, hatched bars) $11 \mathrm{~d}$ earlier.

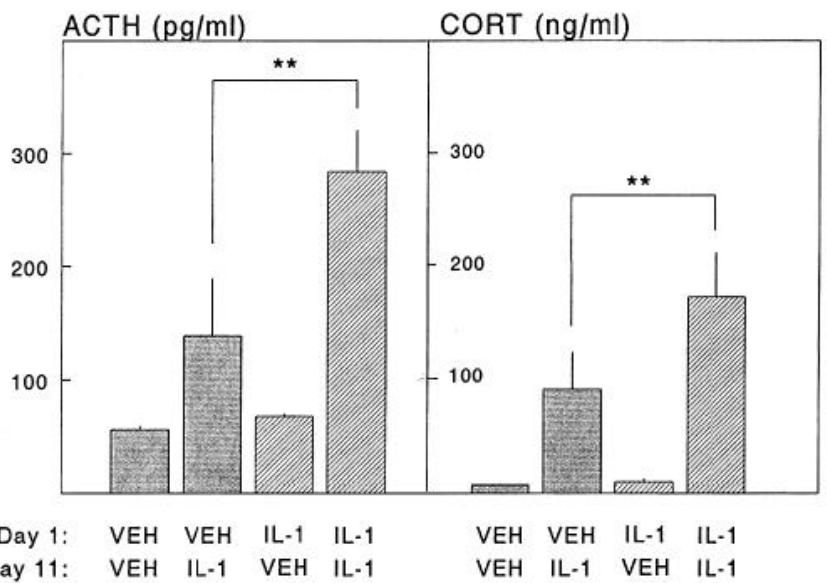

Day 11: VEH IL-1 VEH IL-1 VEH IL-1 VEH IL-1

Figure 5. Effect of IL-1 $\beta$ on plasma ACTH and corticosterone (CORT) concentrations in rats given a single dose of vehicle $(V E H$, gray bars) or IL-1 $\beta$ (IL-1, hatched bars) $11 \mathrm{~d}$ earlier. On day 11 , each group received vehicle or IL-1 $(1 \mu \mathrm{g} / \mathrm{kg})$ and were sacrificed $2 \mathrm{hr}$ later. Data are presented as mean and SEM $(n=6-8),{ }^{* *} p<0.01$.

with a delay of several days and persists for at least 3 weeks, is not accompanied by appreciable changes in the CRH stores. The phenomena described above resemble those seen after prolonged periods (weeks) of chronic (e.g., psychosocial) or repeated stress (e.g., immobilization, hypoglycemia) (De Goeij et al., 1991, 1992a,b; Bartanusz et al., 1993; Tilders et al., 1993). Also, under these conditions a progressive increase in AVP stores is preceded by a period of several days in which AVP stores do not change (De Goeij et al., 1992a). The similarity in the time courses of the AVP changes in the ZEME lead us to propose that slowly developing effects to the first challenge rather than cumulative effects of repeated exposures may underlie the changes seen during chronic or repeated stress.

Electron-microscopic analysis shows that the increase of AVP stores in the ZEME, as observed $11 \mathrm{~d}$ after single administration of IL- $1 \beta$, is accompanied by a $60 \%$ increase of the fraction of the CRH terminals in the ZEME that costore AVP. Because neither the density of the secretory granules in the terminals, nor

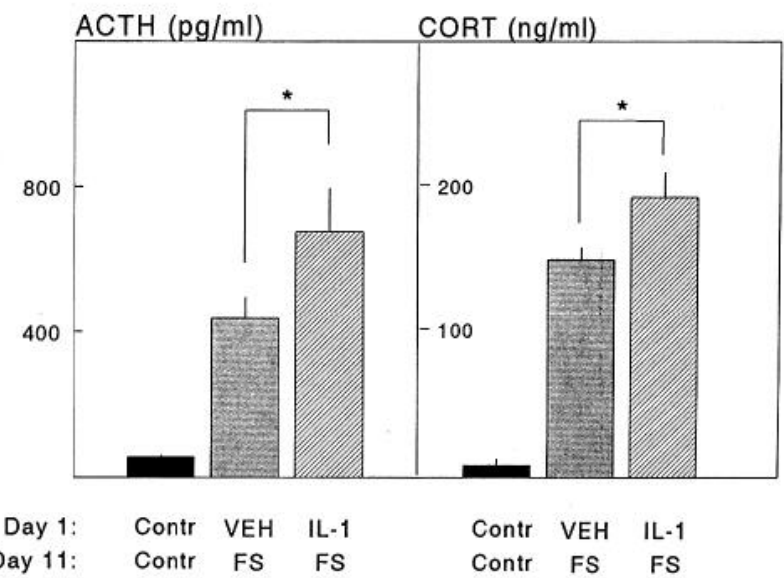

Figure 6. Effect of electric footshocks (FS) on plasma ACTH and corticosterone (CORT) concentrations in rats given a single dose of vehicle (VEH, stippled bars) or IL-1 $\beta$ (IL-1, hatched bars) $11 \mathrm{~d}$ earlier. Twenty minutes after the onset of the footshock session the animals were sacrificed. Black bars: nonshocked controls (Contr). Data are presented as mean and SEM (control: $n=4$; shocked groups: $n=8$ ). ${ }^{*} p$ $<0.05$. 


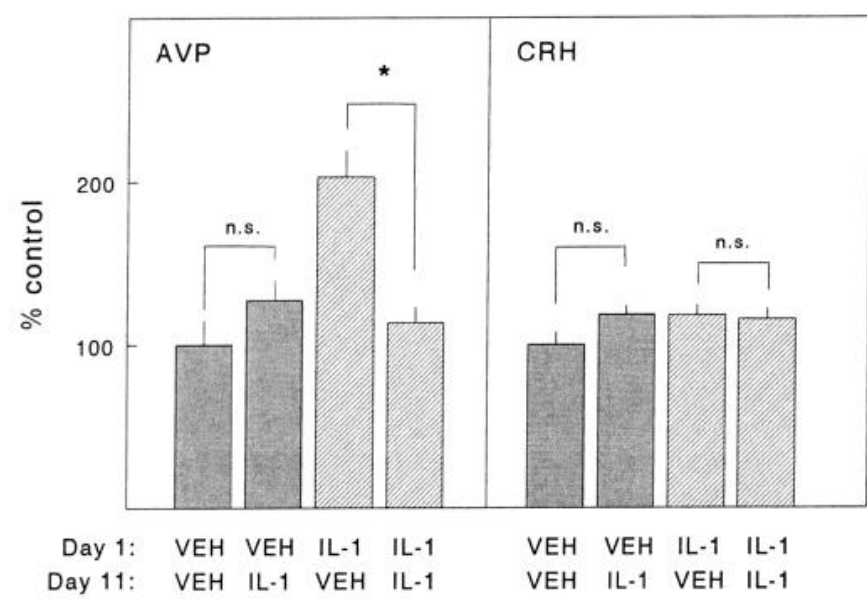

Figure 7. Acute effects of IL- $1 \beta$ on AVP and CRH stores of the ZEME in rats given a single dose of vehicle (VEH, gray bars) or IL$1 \beta$ (hatched bars) $11 \mathrm{~d}$ earlier. For details, see legend of Figure 5. Results are expressed as percentage control (vehicle-challenged group pretreated with vehicle $11 \mathrm{~d}$ earlier: $100 \%$ ). Bars represent mean and SEM $(n=6-8) .{ }^{*} p<0.01$, n.s. not significant.

the $\mathrm{CRH}$ and AVP immunoreactivities of the secretory granules are grossly affected, the increase in the AVP stores appears primarily related to increased numbers of $\mathrm{CRH}$ terminals that costore AVP, as demonstrated in the present study. Because this is associated with increased AVP secretion (see below), we presume that the increase in AVP stores results from increased AVP synthesis in CRH neurons. Recently, we reported similar increases in the fraction and numbers of AVP costoring $\mathrm{CRH}$ terminals of rats exposed to chronic intermittent stress (De Goeij et al., 1991; Bartanusz et al., 1993). This shift in the peptide makeup of CRH nerve terminals in the ZEME was parallelled by an increased fraction of CRH neurons in the mediodorsal part of the PVN that coproduce AVP (De Goeij et al., 1992c) and by increased numbers of parvocellular PVN neurons that express AVP mRNA (Bartanusz et al., 1993). Apparently, chronic intermittent and single exposure to a stressor induce the same form of neuronal plasticity, i.e., transition of non-AVP-producing $\mathrm{CRH}$ neurons into the AVP coproducing phenotype.

A similar increase in the fraction of AVP costoring $\mathrm{CRH}$ terminals in the ZEME and in the proportion of CRH neurons that coproduce AVP or coexpress AVP mRNA, is induced by adrenalectomy (Zimmerman et al., 1977; Bugnon et al., 1983; Tramu et al., 1983; Kiss et al., 1984; Sawchenko et al., 1984; Davis et al., 1986; Sawchenko, 1987; Whitnall et al., 1987a; Bertini and Kiss, 1991). It has been proposed that this phenotypic shift is due to the absence of inhibitory effects of glucocorticoids on AVP production (Sawchenko, 1987). Instead, we previously postulated that hyperactivity of $\mathrm{CRH}$ neurons, which is a common denominator of stress and adrenalectomy, causes CRH neurons to shift from the non-AVP-producing into the AVP-coproducing phenotype (Tilders et al., 1993). Together with our present data, these findings implicate that this phenotypic shift can occur irrespective of the exact paradigm used to activate the CRH neuron. Although the cellular mechanisms underlying the phenotypic changes remain elusive, it should be noted that transcription and translation of the prepro AVP-gene is more sensitive than that of the prepro $\mathrm{CRH}$-gene for the inhibitory actions of corticosteroids (Swanson, 1991; Bertini et al., 1993) and ACTH (Sawchenko, 1989). Therefore, we speculate that reduced effi- cacy of glucocorticoid and/or ACTH feedback may contribute to selective hyperproduction of AVP in CRH neurons.

The mechanism involved in the delay of the IL-1 $\beta$-induced phenotypic shift of $\mathrm{CRH}$ neurons remains enigmatic. In PVN neurons, stressors can increase levels of CRH and AVP mRNAs within 30 min (Suda et al., 1990; Harbuz et al., 1991, 1992; Herman et al., 1992; Imaki et al., 1992) and newly formed peptides can reach the terminals of the ZEME fast enough to maintain AVP and CRH stores in the ZEME at a fairly constant level, even during the course of most stimuli (Berkenbosch et al., 1989a,b; Tilders et al., 1989, 1993; De Goeij et al., 1992a). Therefore, the delayed increase of the AVP stores seems not to be related to intrinsic delays in peptide production or transport. Instead, the slowly developing changes may evolve from singleevent-induced cascades of gene-mediated processes within the $\mathrm{CRH}$ neurons or in the brain circuits involved in the stress response. The latter possibility is supported by the gradual developing (days) and long-lasting (weeks) behavioral and autonomic hyperactivity following exposure of rats to a single session of electric footshocks (van Dijken et al., 1992a,b).

Discordant data have been presented concerning the involvement of AVP in the acute ACTH response to IL-1 $\beta$. We and others reported that IL- $1 \beta$-induced ACTH responses are primarily driven by CRH (Uehara et al., 1987; Sapolsky et al., 1987; Berkenbosch et al., 1987, 1989a; Saphier and Ovadia, 1990; Spinedi et al, 1992). Others focused on the involvement of AVP in these responses (e.g., Whitnall et al., 1992; Watanobe and Takebe, 1993). Our present findings may explain these discordancies, as will be briefly discussed. It can be anticipated that secretion of CRH and/or AVP result in an acute decline of the stores of these peptides in the ZEME. Nonetheless, exposure of naive rats to IL-1 $\beta$ does not lead to overt depletion of the $\mathrm{CRH}$ or AVP stores (present study) because fast axonal transport effectively compensates for peptide losses in the ZEME. Indeed, blockade of fast axonal transport reveals that IL-1 $\beta$ induces a progressive decline of CRH stores (15\% per hour) but does not affect AVP in the ZEME (Berkenbosch et al., 1987, 1989a). This illustrates that IL-1 $\beta$ induces selective release of $\mathrm{CRH}$, possibly by activating non-AVP-producing $\mathrm{CRH}$ neurons in naive rats. In contrast, rats that have been preexposed to IL-1 $\beta 11 \mathrm{~d}$ earlier show a marked IL-1 $\beta$-induced depletion of AVP (present data) even without blockade of axonal transport. These data clearly show that preexposure to IL-1 $\beta$ causes a shift of the ACTH releasing signal towards hypersecretion of AVP in response to a subsequent IL-1 $\beta$ challenge. Therefore, we conclude that the involvement of AVP in the IL- $1 \beta$-induced ACTH secretion depends on the phenotypic state of the $\mathrm{CRH}$ neurons, which is affected by the recent stress or immune history of the animals (long-term effects of single events). In fact, the same may hold for discrepancies reported concerning the contribution of AVP in the control of the ACTH responses to other stressors as well (Berkenbosch et al., 1989b; Plotsky, 1985; Plotsky et al., 1985; De Goeij et al., 1992a).

Because AVP potentiates the ACTH releasing effects of $\mathrm{CRH}$ (Gillies et al., 1982; Rivier and Vale, 1983; Linton et al., 1985; Antoni, 1986) cosecretion of AVP is anticipated to result in a more powerful hypothalamic signal driving the ACTH secretion. Indeed, the ACTH and subsequent corticosterone responses to IL- $1 \beta$ are potentiated in IL- $1 \beta$ preexposed rats as compared to those in vehicle preexposed controls. Exaggerated ACTH and corticosterone responses are also found when IL-1 $\beta$ pretreated rats are exposed to footshocks. This excludes the possibility that 
IIPA hyperresponsivencss is duc to a specific hypersensitivity to IL-1 $\beta$. Taken together, these data made us conclude that the IL$1 \beta$-induced long-lasting phenotypic shift of CRH neurons towards the AVP coproducing phenotype leads to an increased contribution of AVP to the hypothalamic signal driving the ACTH response to a stressor. Also, adrenalectomy and chronic stress-induced increases in AVP stores in the ZEME are associated with increased secretion of AVP (De Goeij et al., 1992a, 1993). Whether or not IL-1-induced increases in AVP stores is also associated with hypersecretion of AVP under resting conditions, is not clear. Our observations at the nadir of the diurnal cycle are not conclusive and require additional information during the zenith of the diurnal cycle, a period during which the plasma ACTH and corticosterone levels are highly dependent on the activity of the hypothalamic CRH neurons (Van Oers and Tilders, 1991, Van Oers et al., 1992).

It should be noted that chronic intermittent stress and longterm adrenalectomy are also accompanied by an increased AVP/ $\mathrm{CRH}$ ratio of the hypothalamic signal driving ACTH secretion (Plotsky and Sawchenko, 1987; Fink et al., 1988; Spinedi et al., 1991; De Goeij et al., 1992a, 1993). However, repeated stress usually does not result in ACTH and corticosterone hyperresponses, unless animals are exposed to a novel stimulus (Amario et al., 1988; Hauger et al., 1990; Rivest and Rivier, 1991; Scribner et al., 1991). Apparently, the increased power of the different elements of the HPA axis (Dallman, 1993) induced by repeated (chronic) stress is compensated for by stimulus-specific habituation processes. In addition, chronic stress can cause hyposensitivity to $\mathrm{CRH}$ and downregulation of $\mathrm{CRH}$ receptors, a process that is facilitated by AVP (Holmes et al., 1987; Hauger et al., 1988). However, because single exposure to IL-1 $\beta$ or footshocks (Mos et al., in preparation) both induce a long-lasting hyperresponsive state, we propose that such habituating mechanisms do not become effective following single exposure to a stressor.

It is known that bacterial infection, surgical trauma, burns, and other forms of tissue injury cause inflammatory responses that lead to the production of IL-1 $\beta$ and other proinflammatory cytokines (Dinarello, 1988; Michie et al., 1988; Cannon et al., 1990; Berkenbosch, 1994; Berzi and Nagy, 1994; Tilders et al., 1994; Hopkins and Rotwell, 1995; Rotwell and Hopkins, 1995). Inflammation is associated with activation of the HPA axis and glucocorticoids are considered to play an essential role in restraining acute phase reactions as well as many steps in humoral and cellular immune responses (Munck et al., 1984; Berkenbosch, 1994; Berzi and Nagy, 1994). Furthermore, IL-1 $\beta$ is known to mediate the acute and transient activation of the HPA axis in response to certain inflammatory stimuli, i.e., endotoxin (e.g., Uehara et al., 1987; DeRijk et al., 1991; Schotanus et al., 1993; Tilders et al., 1994). Because IL-1 $\beta$ induces a delayed and long-lasting hyperresponsiveness of the HPA axis, we speculate that inflammation-associated acute activation of the HPA axis may induce delayed and long-lasting changes in the HPA axis that serve to remodel the immune responses to later challenges.

CRH neurons in the PVN that project to the ZEME form only one element of the CRH system in the brain and CRH neurons, ncrve fibers, as well as $\mathrm{CRH}$ receptors are present in many brain structures (Sawchenko et al., 1993; De Souza and Grigoriadis, 1995). Of these CRH systems, CRH neurons in the PVN are most clearly involved in the coordination of (neuro)endocrine, metabolic, immune, and behavioral aspects of the stress response (Vale et al., 1983; Dunn and Berridge, 1990; Elkabir et al., 1990; Chrousos and Gold, 1992; Bonaz and Taché, 1994). According- ly, in addition to CRH neurons projecting to the ZEME, the PVN also harbors $\mathrm{CRH}$ neurons projecting to various areas in the brainstem that are associated with the control of behavioral and vegetative functions (Swanson et al., 1987; Swanson, 1991; Chrousos and Gold, 1992). Because several behavioral and other effects of $\mathrm{CRH}$ are potentiated by AVP (e.g., Elkabir et al., 1990) our observations raise the challenging possibility that long-term hyperproduction and hypersecretion of AVP, as found for the $\mathrm{CRH}$ neurons that control ACTH secretion, may also apply for $\mathrm{CRH}$ neurons in the PVN controlling other functions. If so, the long-lasting behavioral, autonomic, and (neuro)endocrine stress-hyperresponses induced by single exposure to electric footshocks (van Dijken et al., 1992a,b) and to IL-1 $\beta$ (present study) may relate to phenotypic changes (hyperproduction, -storage, and -release of AVP) in such CRH neurons. This possibility, that needs to be studied in further detail, may have major consequences for our understanding of stress hypersensitivity syndromes.

\section{References}

Aguilera G, Kiss A, Hauger R, Tizabi Y (1992) Regulation of the hypothalamic-pituitary-adrenal axis during stress: role of neuropeptides and neurotransmitters. In: Stress: neuroendocrine and molecular approaches (Kvetnansky R, McCarty R, Axelrod J, eds), pp 365-381. New York: Gordon and Breach Science.

Amario A, Hidalgo J, Giralt M (1988) Evidence that the pituitaryadrenal axis does not cross-adapt to stressors: comparison to other physiological variables. Neuroendocrinology 47:263-267.

Antoni, FA (1986) Hypothalamic control of adrenocorticotropin secretion: advances since the discovery of 41 -residue corticotropin-releasing factor. Endocr Rev 7:351-378.

Bartanusz V, Jezova D, Bertini LT, Tilders FJH, Aubry JM, Kiss JZ (1993) Stress-induced increase in vasopressin and corticotropin-releasing factor expression in hypophysiotrophic paraventricular neurons. Endocrinology 132:895-902.

Ben-Barak Y, Russel JI, Whitnall MH, Ozato K, Gainer H (1985) Neurophysin in the hypothalamo-neurohypophysial system 1. Production and characterization of monclonal antibodies. J Neurosci 5:81-97.

Berkenbosch F (1994) Neuroendocrine responses to physical trauma. In: Brain control of responses to trauma (Rothwell NJ, Berkenbosch F, eds), pp 239-259. Cambridge, UK: Cambridge UP.

Berkenbosch F, Tilders FJH (1988) Effect of axonal transport blockade on corticotropin-releasing factor immunoreactivity in the median eminence of intact and adrenalectomized rats: relationship between depletion rate and secretory activity. Brain Res 442:312-320.

Berkenbosch F, Van Oers JWAM, del Rey A, Tilders FJH, Besedovsky HO (1987) Corticotropin-releasing factor-producing neurons in the rat activated by interleukin-1. Science 238:524-526.

Berkenbosch F, De Goeij DCE, Rey AD, Besedovsky HO (1989a) Neuroendocrine, sympathetic and metabolic responses induced by interleukin-1. Neuroendocrinology 50:570-576.

Berkenbosch F, De Goeij DCE, Tilders FJH (1989b) Hypoglycemia enhances turnover of corticotropin-releasing factor and of vasopressin in the zona externa of the rat median eminence. Endocrinology 125: $28-34$.

Bertini LT, Kiss JZ (1991) Hypophysiotrophic neurons are capable of altering the ratio of co-packaged neurohormones. Neuroscience 42: 237-244.

Bertini LT, Kursner C, Gaillard RC, Corder R, Kiss JZ (1993) A tissue culture model of the hypophysiotrophic CRF producing neuronal system. Neuroendocrinology 57:716-728.

Berzi J, Nagy E (1994) Neurohormonal control of cytokines during injury. In: Brain control of responses to trauma (Rothwell NJ, Berkenbosch F, eds), pp 32-108. Cambridge, UK: Cambridge UP.

Bonaz B, Taché Y (1994) Water-avoidance stress-induced c-fos expression in the rat brain and stimulation of fecal output: role of corticotropin-releasing factor. Brain Res 641:21-28.

Bugnon C, Fellmann D, Gouget A (1983) Changes in corticoliberin and vasopressin-like immunoreactivities in the zona externa of the median eminence in adrenalectomized rats. Immunocytochemical study. Neurosci Lett 37:43-49. 
Cannon JG, Tomkins RG, Gelfand JA, Michie HR, Stanford GG, Van der Meer JWM, Endres S, Lonneman G, Corsetti J, Chernow B, Wilmore DW, Wolff SM, Burke JF, Dinarello CA (1990) Circulating interleukin- 1 and tumor necrosis factor in septic shock and experimental endotoxin fever. J Infect Dis 161:79-84.

Chrousos GP, Gold PW (1992) The concepts of stress and stress system disorders. Overview of physical and bchavioral homcostasis. JAMA 267:1244-1252.

Dallman MF (1993) Stress update adaptation of the hypothalamicpituitary-adrenal axis to chronic stress. Trends Endocrinol Metabol 4:62-69.

Davis LG, Arentzen R, Reid J, Manning RW, Wolfson B, Lawrence K, Baldino F (1986) Glucocorticoid sensitivity of vasopressin mRNA levels in the paraventricular nucleus of the rat. Proc Natl Acad Sci ISA 83:1145-1149.

De Goeij DCE. Kvetnansky R, Whitnall MH, Jezova D, Berkenbosch F, Tilders FJH (1991) Repeated stress-induced activation of corticotropin-releasing factor neurons enhances vasopressin stores and colocalization with corticotropin-releasing factor in the median eminence of rats Neuroendocrinology 53:150-159.

De Goeij DCE, Binnekade R, Tilders FJH (1992a) Chronic stress enhances vasopressin but not corticotropin-releasing factor secretion during hypoglycemia. Am J Physiol 263:E394-E399.

De Goeij DCE, Dijkstra H, Tilders FJH (1992b) Chronic psychosocial stress enhances vasopressin, but not corticotropin-releasing factor, in the external zone of the median eminence of male rats: relationship to subordinate status. Endocrinology 131:847-853.

De Goeij DCE, Jezova D, Tilders FJH (1992c) Repeated stress enhances vasopressin synthesis in corticotropin releasing factor neurons in the paraventricular nucleus. Brain Res 577:165-168.

De Goeij DCE, Jezova D, Tilders FJH (1992d) Chronic stress and adrenalectomy both induce vasopressin synthesis and storage in corticotropin releasing factor neurons in the paraventricular nucleus. In: Stress: neuroendocrine and molecular approaches (Kvetnansky $\mathrm{R}$, McCarty R, Axelrod J, eds), pp 273-285. New York: Gordon and Breach Science.

De Goeij DCE, Berkenbosch F. Tilders FJH (1993) Is vasopressin preferentially released from corticotropin-releasing factor and vasopressin containing nerve terminals in the median eminence of adrenalectomized rats? J Neuroendocrinol 5:107-113

De Man AJM, Benraad TJ (1977) Aldosterone secretion rate: radioimmunoassay versus double isotope dilution derivative assay. Clin Chim Acta 79:489-501.

DeRijk RH, Van Rooijen N, Berkenbosch F (1991) The role of macrophages in the pituitary-adrenal activation in response to endotoxin (LPS). Res Immunol 143:224-229.

De Souza EB, Grigoriadis DE (1995) Corticotropin releasing factor physiology, pharmacology, and role in central nervous system and immune disorders. In: Psychopharmacology: the fourth generation of progress (Bloom FE, Kupfer DJ, eds), pp 505-517. New York: Raven.

Dinarello CA (1988) Biology of interleukin 1. FASEB J 2:108-115.

Dunn AJ, Antoon M, Chapman Y (1991) Reduction of exploratory behavior by intraperitoneal injection of interleukin- 1 involves brain corticotropin releasing factor. Brain Res Bull 26:539-542.

Elkabir DR, Wyatt ME, Vellucci SV, Herbert J (1990) The effects of separate or combined infusions of corticotrophin-releasing factor and vasopressin either intraventricularly or into the amygdala on aggressive and investigative behaviour in the rat. Regul Pept 28:199-214.

Fink G, Robinson IC, Tannahill LA (1988) Effects of adrenalectomy and glucocorticoids on the peptides CRF-4I, AVP and oxytocin in rat hypophysial portal blood. J Physiol (Lond) 40:329-345.

Gillies GE, Linton EA, Lowry PJ (1982) Corticotropin releasing activity of the new CRF is potentiated several times by vasopressin. Nature 299:355-357.

Harbuz M, Russell JA, Sumner BE, Kawata M, Lightman SL (1991) Rapid changes in the content of proenkephalin $A$ and corticotrophin releasing hormone mRNAs in the paraventricular nucleus during morphine withdrawal in urethane-anaesthetized rats. Brain Res Mol Brain Res 9:285-291.

Harbuz MS, Stephanou A, Sarlis N, Lightman SL (1992) The effects of recombinant human interleukin (IL)- 1 alpha, IL-1 beta or IL- 6 on hypothalamo-pituitary-adrenal axis activation. J Endocrinol 133: 349-355.

Hauger RL. Millan MA, Lorang M, Harwood JP, Aguilera G (1988)
Corticotropin-releasing factor receptors and pituitary adrenal responses during immobilization stress. Endocrinology 123:396-405.

Hauger RL, Lorang M, Irvin M, Aguilera G (1990) CRH receptor regulation and sensitization of ACTH responses to acute ether stress during chronic intermittent immobilization stress. Brain Res 532:3440.

Herman JP, Schafer MK, Thompson RC, Watson SJ (1992) Rapid regulation of corticotropin-releasing hormone gene transcription in vivo. Mol Endocrinol 6:1061-1069.

Holmes MC, Catt KJ, Aguilera G (1987) Involvement of vasopressin in the down-regulation of pituitary corticotropin-releasing factor receptors after adrenalectomy. Endocrinology 121:2093-2098.

Hopkins SJ, Rothwell NJ (1995) Cytokines and the nervous system I: Expression and recognition. Trends Neurosci 18:83-88.

Imaki T, Shibasaki T, Hotta M, Demura H (1992) Early induction of c-fos precedes increased expression of corticotropin-releasing factor messenger ribonucleic acid in the paraventricular nucleus after immobilization stress. Endocrinology 131:240-246.

Kiss JZ, Mezey E, Skirboll L (1984) Corticotropin-releasing factorimmunoreactive neurons of the paraventricular nucleus become vasopressin positive after adrenalectomy. Proc Natl Acad Sci USA 81: $1854-1858$

Koenig JI, Klippel RA. The rat brain (1963) A stereotactic atlas of the forebrain and lower parts of the brainstem. Baltimore, MD: Williams and Wilkins.

Kovacs KJ, Makara GB (1988) Corticosterone and dexamethasone act at different brain sites to inhibit adrenalectomy induced adrenocorticotropin hypersecretion. Brain Res 474:205-210.

Linton EA, Tilders FJH, Hodgkinson SC, Berkenbosch F, Vermes I, Lowry PJ (1985) Stress-induced secretion of adrenocorticotropin in rats is inhibited by administration of antisera to ovine corticotropinreleasing factor and vasopressin. Endocrinology 116:966-970.

Michie HR, Manogue KR, Spriggs DR (1988) Detection of circulating tumor necrosis factor after endotoxin administration. $N$ Eng J Med 318:1481-1486.

Munck A, Guyre PM, Holbrook NJ (1984) Physiological functions of glucocorticoids in stress and their relationships to pharmacological actions. Endocrinol Rev 5:25-44.

Plotsky PM (1985) Hypophyseotropic regulation of adenohypophyseal adrenncorticotropin secretion. Fed Proc 44:207-213.

Plotsky PM, Bruhn TO, Vale WW (1985) Hypophysiotropic regulation of adrenocorticotropin secretion in response to insulin-induced hypoglycemia. Endocrinology 117:323-329.

Plotsky PM, Sawchenko PE (1987) Hypophysial-portal plasma levels, median eminence content, and immunohistochemical staining of corticotropin-releasing factor, arginine vasopressin, and oxytocin after pharmacological adrenalectomy. Endocrinology 120:1.361-1369.

Rivest C, Rivier C (1991) Influence of the paraventricular nucleus of the hypothalamus in the alteration of neuroendocrine functions induced by intermittent footshocks or interleukin. Endocrinology 129: 2049-2057.

Rivier C, Vale WW (1983) Modulation of stress-induced ACTH release by corticotropin-releasing factor, catecholamines and vasopressin. Nature 305:325-327.

Romero LM, Plotsky PM, Sapolsky RM (1993) Patterns of adrenocorticotropin secretagogue release with hypoglycemia, novelty, and restraint after colchicine blockade of axonal transport. Endocrinology 132:199-204.

Rothwell NJ, Hopkins J (1995) Cytokines and the nervous system II: actions and mechanisms of action. Trends Neurosci 18:1,30-1.36.

Saphier D, Ovadia H (1990) Selective facilitation of putative corticotropin-releasing factor-secreting neurones by interleukin-1. Neurosci Lett 114:283-288.

Sapolsky RM, Rivier C, Yamamoto G, Plotsky PM, Vale WW (1987) Interleukin- 1 stimulates the secretion of hypothalamic corticotropinreleasing factor. Science 238:522-524.

Sawchenko PE (1987) Adrenalectomy-induced enhancement of CRF and vasopressin immunoreactivity in parvocellular neurosecretory neurons: anatomic, peptide, and steroid specificity. J Neurosci 7:1093-1106.

Sawchenko PE (1989) Short-loop feedback effects of adrenocorticotropic hormone on corticotropin-releasing factor and vasopressin immunoreactivity in the paraventricular nucleus. Soc Neurosci Abstr 1.3: 1371 .

Sawchenko PE, Swanson LW, Vale, WW (1984) Co-expression of cor- 
ticotropin-releasing factor and vasopressin immunoreactivity in parvocellular neurosecretory neurons of the adrenalectomized rat. Proc Natl Acad Sci 81:1883-1887.

Sawchenko PE, Imaki T, Potter E, Kovacs K, Imaki J, Vale W (1993) The functional neuroanatomy of corticotropin-releasing factor. In: Corticotropin-releasing factor (Chadwick DJ, Marsh J, Ackrill K. eds), pp 5-29. Chichester, UK: Wiley.

Schotanus K, Tilders FJH, Berkenbosch F (1993) Human recombinant interleukin-1 receptor antagonist prevents $\mathrm{ACTH}$ but not interleukin- 6 responses to low doses of bacterial endotoxin rats. Endocrinology 133:2461-2468.

Scribner KA, Walker CD, Cascio CS, Dallman MF (1991) Chronic streptozotocin diabetes in rats facilitates the acute stress response without altering pituitary or adrenal responsiveness to secretagogues. Endocrinology 129:99-108.

Spinedi E, Giacomini M, Jacquier MC, Gaillard RC (1991) Changes in the hypothalamo-corticotrope axis after bilateral adrenalectomy: evidence for a median eminence site of glucocorticoid action. Neuroendocrinology 53:160-170.

Spinedi E, Hadid R, Daneva T, Gaillard RC. (1992) Cytokines stimulate CRH but not the vasopressin neuronal system: evidence for a median eminence site of interleukin-6 action. Neuroendocrinology 56:46-53.

Suda T, Tozawa F, Ushiyama T, Sumitomo T, Yamada M, Demura H (1990) Interleukin-1 stimulates corticotropin-releasing factor gene expression in rat hypothalamus. Endocrinology 126:1223-1228.

Swanson LW (1991) Biochemical switching in hypothalamic circuits mediating responses to stress. Prog Brain Res 87:181- 200.

Swanson LW, Sawchenko PE, Lind RW (1987) The CRH motoneuron: differential peptide regulation in neurons with possible synaptic, paracrine, and endocrine outputs. Ann NY Acad Sci 512:12-23.

Tilders FJH, De Goeij DCE. Berkenbosch F (1989) Turnover of corticotropin releasing factor and vasopressin in the median eminence and control of pituitary-adrenal activity. In: The control of the hypothalamo pituitary adrenal axis (Rose FJ, ed), pp 7-24. Madison, WI: International UP.

Tilders FJH, Schmidt ED, De Goeij DCE (1993) Phenotypic plasticity of CRF neurons during stress [Review]. Ann NY Acad Sci 697:3952.

Tilders FJH, DeRijk RH, Van Dam A, Vincent VAM, Schotanus K, Persoons JHA (1994) Activation of the hypothalamus-pituitary-adrenal axis by bacterial endotoxins: routes and intermediate signals. Psychneuroendocrinology 19:209-232.

Tramu G, Croix C, Pillez A (1983) Ability of the crf immunoreactive neurons of the paraventricular nucleus to produce a vasopressin-like material immunohistochemical demonstration in adrenalectomized guinea pigs and rats. Neuroendocrinology 37:467-469.

Uehara A, Gottschall PE, Dahl RR, Arimura A (1987) Interleukin-1 stimulates ACTH release by an indirect action which requires endogenous corticotropin releasing factor. Endocrinology 121:1580-1582.

Vale W, Rivier C, Brown MR, Spiess J, Koob G, Swanson L, Bilezikjian L, Bloom F, Rivier J ( 1983) Chemical and biological characterization of corticotropin releasing factor. Rec Prog Horm Res 39:245-270.

Van der Sluis PJ, Pool CW, Sluiter AA (1988) Immunochemical detection of peptides and proteins on press-blots after direct tissue gel isoelectric focussing. Electrophoresis 9:654-661.

Van Dijken HH, Mos J, van der Heyden JA, Tilders FIH (1992a) Char- acterization of stress-induced long-term behavioural changes in rats: evidence in favor of anxiety. Physiol Behav 52:945-951.

Van Dijken HH, van der Heyden JA, Mos J, Tilders FJH (1992b) Inescapable footshocks induce progressive and long-lasting behavioural changes in male rats. Physiol Behav 51:787-794.

Van Dijken HH, De Goeij DCE, Sutanto W, Mos J, de Kloet ER, Tilders FJH (1993) Short inescapable stress produces long-lasting changes in the brain-pituitary-adrenal axis of adult male rats. Neuroendocrinology 58:57-64.

Van Oers JWAM, Tilders FJH (1991) Non-adrenocorticotropin mediated effects of endogenous corticotropin-releasing factor on the adrenocortical activity in the rat. $J$ Neuroendocrinol 3:119-121.

Van Oers JWAM, Hinson JP, Binnekade R, Tilders FJH (1992) Physiological role of corticotropin-releasing factor in the control of adrenocorticotropin-mediated corticosterone release from the rat adrenal gland. Endocrinology 130:282-288.

Watanobe H, Takebe K (1993) Intrahypothalamic perfusion with interleukin-1-beta stimulates the local release of corticotropin-releasing hormone and arginine vasopressin and the plasma adrenocorticotropin in freely moving rats: a comparative perfusion of the paraventricular nucleus and the median eminence. Neuroendocrinology 57: 593-599.

Whitnall MH (1988) Distributions of pro-vasopressin expressing and pro-vasopressin deficient CRH neurons in the paraventricular hypothalamic nucleus of colchicine-treated normal and adrenalectomized rats. J Comp Neurol 275:13-28.

Whitnall MH (1993) Regulation of the hypothalamic corticotropin-releasing hormone neurosecretory system. Prog Neurobiol 40:573629.

Whitnall MH, Gainer H (1988) Major pro-vasopressin-expressing and pro-vasopressin-deficient subpopulations of corticotropin-releasing hormone neurons in normal rats. Differential distributions within the paraventricular nucleus. Neuroendocrinology 47:176-180.

Whitnall MH, Key S, Ben-Barak Y, Ozato K, Gainer H (1985a) Neurophysin in the hypothalamo-neurohypophysial system 2 . Immunocytochemical studies of the ontogeny of oxytocinergic and vasopressinergic neurons. J Neurosci 5:98-109.

Whitnall MH, Mezey E, Gainer H (1985b) Co-localization of corticotropin-releasing factor and vasopressin in median eminence neurosecretory vesicles. Nature 317:248-250.

Whitnall MH, Key S, Gainer H (1987a) Vasopressin-containing and vasopressin-deficient subpopulations of corticotropin-releasing factor axons are differentially affected by adrenalectomy. Endocrinology 120:2180-2182.

Whitnall MH, Smyth DG, Gainer H (1987b) Vasopressin coexists in half of the corticotropin-releasing factor axons present in the external zone of the median eminence in normal rats. Neuroendocrinology 45: $420-424$

Whitnall MH, Perlstein RS, Mougey EH, Neta R (1992) Effects of interleukin- 1 on the stress-responsive and -nonresponsive subtypes of corticotropin-releasing hormone neurosecretory axons. Endocrinology $131: 37-44$.

Zimmerman EA, Stillman MA, Recht LD, Antunes JL, Carmel PW, Goldsmith PC (1977) Vasopressin and corticotropin-releasing factor: an axonal pathway to portal capillaries in the zona externa of the median eminence containing vasopressin and its interaction with adrenal corticoids. Ann NY Acad Sci 297: 405 419. 